\section{Immunology 58, 271-276}

42 Katz, D.R., Feldmann, M., Tees, R. and Schreier, M.H. (1986) Immunology 58, 167-172

43 Brennan, A., Katz, D.R., Nunn, J.D. et al. (1987) Immunology 61, 457-461

44 Nage!kerken, L.M. and van Breda Vriesman, P.J.C. (1986) J. Inmunol. 136, 2164-2170

45 Bhardwaj, N., Lau, L.L., Friedman, S.M., Crow, M.K. and Steinman, R.M. (1989) J. Exp Med. 169, 1121-1136

46 Koide, S. and Steinman, R.M. (1987) Proc. Natl Acad. Sci. USA 84, 3802-3806

47 Koide, S. and Steinman, R.M. (1988) J. Exp. Med. $16 \overline{\text {, }}$ $409-416$

48 Koide, S., Inaba, K. and Steinman, R.M. (1987) J. Exp.

Med. 165, 515-530

49 Kawakami, K., Kakimoto, K., Shinbori, T. and Inoue, K. (1989) Immunology 67, 314-320

50 Heufler, C., Koch, F. and Schuler, G. (1988) J. Exp. Med. 167, 700-705

51 Inaba, K. and Steinman, R.M. (1984) J. Exp. Med. 160. 1717-1735

52 Ramila, G. and Erb, P. (1983) Nature 304, 442-443

53 King, P.D. and Katz, D.R. (1989) Leucocyte Differentiation Antigens IV, pp. 503-505, Oxford University Press

54 Trowbridge, I.S., Lesley, J.F., Domingo, D. et al. (1987) Methods Enzymol. 147, 265-279

55 Romani, N., Inaba, K., Pure, E. et al. (1989) j. Exp. Med. $169,1153-1168$

56 Inaba, K., Steinman, R.M., van Voorhis, W.C. and Muramutsu, S. (1983) Proc. Natl Acad. Sci. USA 80. 6041-6045

57 Francotte, M. and Urbain, J. (1985) Proc. Natl Acad. Sci. USA 82, 8149-8152
58 Nussenzweig, M.C., Steinman, R.M., Gutchinov, B. and Cohn, Z.A. (1980) J. Exp. Med. 152, 1070-1084

59 Czitrom, A.A., Katz, D.R. and Sunshine, G.H. (1382) Immunology 45, 5j3-560

60 Boog, C.J.P., Boes, J. and Melief, C.J.M. (1988) Eur. J. Immunol. 18, 219

61 Inaba, K., Ýcung, I.W. and Steinman, R.M. (1987) J. Exp. Med. 166, 182-194

62 Macatonia, S.E., Taylor, P M., Knight, S.C. and Askonas, 3.A. (1989) J. Exp. Med. 169, 1255-1264

63 Biberfeld, P., Ost, A., Porwit, A. et al. (1987) Acta Pathol. Microbiol. Scand. Ser. C 95, 47-65

64 Macatonia, S.E., Patteron, S. and Knight, S.C. (1989) Immunology 67, 285-289

65 Hildreth, J.E.K. and Orentas, R.J. (1989) Science 244, 1075-1078

66 Tyndall, A.D., Knight, S.C., Edwards, A.!. and Clarke, J.B. (1983) Lancet i, 472-473

67 Zvaifler, N.J., Steinman, R.M., Kaplan, G., Lau, L.L. and Rivellis, M. (1985) J. Clin. Invest. 76, 789-800

68 Duke, O., Panayi, G.S., Jariossy, G. and Poulter, L.W. (1982) Clin. Exp. Immunol. 49, 22-30

69 Knight, S.C., Mertin, J., Stackpole, A. and Clark, J. (1983) Proc. Natl Acad. Sri. USA 80, 6032-6035

70 Lechler, R.I. and Batchelor, J.R. (1982); Exp. Med. 155. $31-43$

71 Jalkanen, S., Steere, A.C., Fox, R.I. and Butcher, E.C. (1986) Science 233̈, 556-558

72 Austyn, J.M., Kupiec-Wegiiriski, j.W., Hankins, D.F. and Morris, P.J. (1988) J. Exp. Med. 167, 646-654

73 Katz, D.R. (1984) Immunol. Today 5, 96-97

74 Shah, P.D., Keij, J., Gilbertson, S.M. and Rowley, D.A. (1986) J. Exp. Med. 163, 1012-1017

\title{
Role of the CD28 receptor in T-cell activation
}

Antigen-specific T-cell activation is initiated through the T-cell receptor. Recent evidence has shown that a number of additional T-cell surface receptors serve to regulate the responses of antigen-activated $T$ cells. One such molecile, CD28, is a member of a heterophilic cell adhesion complex, and is the receptor for the B-cell-restricted B7/BB-1 antigen. As Carl June, Jeffrey Ledbetter, Peter Linsley and Craig Thompson review here, CD28 serves as the surface component of a novel signal transduction pathway that modulates $T$-cell lymphokine production and increases the resistance of $T$-cell responses to various immunosuppressive agents.

Interaction between the $T$ cell and antigen that is expressed in conjunction with either MHC class I or class II molecules on an antigen-presenting celi initiates a cascade of biochemical events that collectively are termed antigen-specific T-cell activation. However, while the en-

'Naval Medical Research Institute, Bethesda, MD 20814, USA; 2 Oncogen Corp., Seattle, WA 98121, USA and ${ }^{3}$ Howard Hughes Medical Institute, University of Michigan, Ann Arbor, MI 48109, USA.

\section{Carl H. June', Jeffrey A. Ledbetter2, Peter S. Linsley 2 and Craig B. Thompson ${ }^{3}$}

gagement of the T-cell receptor (TCR) with antigen is required for the initial steps in cell activation, TCR stimulation is not a sufficient signal to account for all the observed events that occur during activation. An increasing number of molecules on the surface of T cells have been implicated in regulating the transition of a resting $T$ cell to blast transformation, and subsequent proliferation and differentiation ${ }^{1.2}$. These molecules have beer, termed accessory molecules because they may function to replace or bypass the need for antigen-presenting cells. In many instances, the binding of ligands to accessory molecules has been shown to augment the biochemical signals provided by the T-cell receptor. In other cases, accessory molecules have been implicated in T-cell adhesion. However, recent evidence suggests that at least one such accessory molecule, $C D 28$, initiates or regulates a signal transduction pathway that is distinct from those stimulated by the TCR complex. 


\section{Physiologic role of the $\mathrm{CO} 28$ receptor}

The binding of monoclonal antibody to the CD28 receptor has been shown to modulate the production of lymphokines by T cells stimulated with lectins or anti-TCR/ CD3 monoclonal antibodies. Lymphokine pioduction by cells co-stimulated with anti-CD28 a.:ibodies is relatively resistant to immunosuppressive agents such as cyclosporine, prostaglandins and vitamin $D_{3}$ in comparison with cells stimulated through the ontigen receptor alone (see below). This suggests that the CD28 activation pathway may play a role in rendering $T$-cell respor ses resistant to standard immunosuppressants in vivo. Preliminary evidence suggests that the natural ligand for CD28 is an activation antigen expressed on the surface of $\mathrm{B}$ cells (see below). A role for the natural ligand in the activation of $T$ cells by antigen-presenting calls is suggested by the ability of anti-CD28 antibodies to inhibit the induction of T-cell proliferation in response to alloantigen ${ }^{3.4}$. Therefore, CD28 may affect in vivo immune responses by functioning botin as a cell adriesion molecule linking $B$ and T lymphocytes and as the surface component of a novel signal transduction pathway.

\section{Characterization of the CD28 surface receptor}

$\mathrm{CD} 28$ was first identified as a $44 \mathrm{kDa}$ homodimeric glycoprotein expressed on $80 \%$ of human peripheral blood T cells that is recognized by the monoclonal antibody 9.3 (Ref. 5). Severa! antibodies to CD28 now exist, all apparentiy directed against the same epitope (Tabie 1). The antigen was initially termed T44 or Tp44, and was designated CD28 at the Third International Workshcp on Human Leukocyte Differentiation Antigens in 1987. CD28 is disulfide-bonded and exh:ioits charge heterogeneity that is due, in part, to variable sialylation ${ }^{6,7}$. In leukemic cell lines, CD28 exists in both monomeric and homodimeric forms? ${ }^{7}$. It is not yet known if free subunits and disulfige-bonded dimers co-exist on the surface of primary $T$ cells. The CDNA clone for $\mathrm{CD} 28$ predicts a transmembrane protein that contains 202 residues $^{8}$. The extraceliular jomain of CD28 contains 134 amino acids with five $\boldsymbol{N}$-linked glycosylation sites and is homologous to immunoglobulin variable region domains. The immunoglobulin-like nature of CD28 suggested that it was a receptor for an uncharacterized ligand (see below). Transfection of CD28 CDNA into COS cells results in the surface expression of homodimeric piotein ${ }^{8}$.

A small and variabie proportion (approximately $5 \%$ ) of immature $\mathrm{CD}^{-}$- thym.ocytes are $\mathrm{CD}^{2} 8^{+}$(kefs 9,10 ). During T-cell maturation in the thymus, CD28 is expressed at very low density on the surface of most $C D 4^{+} C D 8^{+}$ (double-positive) immature thymocytes. As thymocytes mature, CD28 expression is enhanced: CD28 is found at higher density on essentially all mature $C D 3^{\text {high }}+, C D 4^{+}$or $\mathrm{CD} 8$ + (single-positive) thymocytes. CD28 expression is further enhanced by activation ${ }^{9}$. In contrast, on!y $80 \%$ of peripheral blood T cells express $C D 28$. In peripheral blood, approximately $95 \%$ of $\mathrm{CD4}^{+} \mathrm{T}$ cells and approximately $50 \%$ of $\mathrm{CD}^{+} \mathrm{T}$ cells bear the CD28 antiger ${ }^{11}$. CD28- T cells expiess CD 1 1b; approximately $1-5 \%$ of $C D 3^{+} C D 4^{+}$ and approximately $50 \%$ of $C D 3^{+} C D 8^{+}$cells are $C D 11 b^{+-}$ CD28- (Refs 11,12). Recent studies indicate that the minor pepulation of $\mathrm{CD}^{+} \mathrm{CD} 4^{+} \mathrm{CD28}-$ cells has limited TCR diversity ${ }^{3}$. It has been suggested that this population may not undergo selection in the thymus ${ }^{13}$, a possibility consistent with the inability to demonstrate $\mathrm{CD} 3^{\text {hight. }}$
Table 1. Anti-CD28 antibcdies

\begin{tabular}{lll}
\hline Monoclonal antibsdy & lg subclass & Laboratory of origin \\
\hline human & & \\
93 & murine $\operatorname{lgG} 2 \mathrm{a}$ & P. Martin and J. Hansen \\
Kolt-2 & murine $\operatorname{lgG1}$ & K. Okubo \\
$15 E 8$ & murine lgG1 & R. van Lier \\
248.23 .2 & murine lgM & L. Moretta
\end{tabular}

\section{murine}

37.51.1 hamster J. Allison

CD28- single-positive cells in the thymus9.10. Similarly, the developmental path of the $\mathrm{CD} 3{ }^{+} \mathrm{CD} 8+\mathrm{CD} 28$ - cells found in the peripheral blood remains undetermined Surface expression of $C D 28$ was originally thought to be specific for lymphocytes of the T lineage, however more recent studies have shown that $C D 28$ is expressed on the surface of plasma cells ${ }^{14}$.

In studies of T-cell clones, surface expression of CD28 was reported to be restricted to T cells that express the $\boldsymbol{\alpha} \boldsymbol{\beta}$ TCR heterodimer ${ }^{15}$. However, this is likely to represent heterogeneity among lymphocyte donors since in bulk cultures of proliferating primary T celis, others detect high expression of CD28 on T cells expressing either the $\alpha \beta$ or $\gamma \delta$ forms of the TCR ${ }^{15}$. The density of CD28 expression divides $\mathrm{CD} 4{ }^{+} \mathrm{T}$-cell clones into two functionally distinct subsets ${ }^{17}$. One subset produces interleukin 2 (IL-2), gamma-interferon (IFN- $\gamma$ ), and tumor necrosis factor $\alpha$ (TNF- $\alpha$ ) and can display anti-CD3-mediated cytotoxicity. The other subset of $\mathrm{CD4}^{+}$clones produces minimal amounts of lymphokines, and is not cytotoxic. High CD28 surface expression was found on the clones without cytotoxic function, and low CD28 expression on the cytotoxic clones. The significance of these findings is not ciear in view of the observation that prolonged culture of $T$ cells in the presence of IL- 2 is associated with decreased surface expression of CD28 (Ref. 16).

$\mathrm{CD} 8^{+} \mathrm{CD}^{2} 8^{+}$and $\mathrm{CD} 8^{+} \mathrm{CD28} 8^{-}$celis can be distinguished by cellular assays of cytotoxic and suppressor function, in thiat cells capable of MHC-restricted cytotoxicity are confined to the $C D 8^{+} C D 28^{+}$subset "1. The abiiity of $C D 28^{+} T$ cells to provide $\mathrm{B}$-cell help for immunoglobulin synthesis and of CD28- T cells to suppress immunoglobulin synthesis ${ }^{18}$ is consistent with the distribution of CD28 across the CD4 and CD8 subsets.

A molecule homologous to $C D 28$ is also expressed on the surface of primate and murine lymphocytes. Primate CD28 is quite similar to human CD28 in that mAb 9.3, a murine anti-human $C D ? 8$ mAb, bind's to macaque lymphocytes and has agonistic effects that are similar to those found on human lymphocytes ${ }^{19}$. Using a molecular approach, J. Allison and colleagues have recently cloned the murine homologue of CD28. Preiiminary experiments indicate that murine CD28 has an equivalent pattern of expression as the human antigen. A monoclonal antibody that recognizes murine $C D 28$ has functional properties similar to human anti-CD28 (Ref. 20).

\section{Functional effects of CD28 stimulation \\ Mitugenic effects}

As will be discussed below, the functional elfects of the CD28 receptor are highly dependent on the manner of 
stimulation, principa'ly as a result of variation in the degree of receptor oligomerization. Gmünoer and Lesslauer $^{21}$ were the first to observe that the biriding of bivalent anti-CD28 mAb could augment T-cell proliferation after suboptimai doses of phytohemagglutinin. Subsequent reports showed that CD28 stimulation also caused marked augmeritation of T-cell proliferation in conjunction with suboptimal stimulation by mAbs that crosslinked the $T C R^{6,22}$. A similar interaction between the CD2 and CD28 receptors was shown in studies where anti-CD28 mAbs augmented the proliferation of mature $T$ cells stimulated with suboptimal amounts of $\mathrm{CD} 2$ mAbs 23,24 . Interestingly, the proliferative effect of CD28 is not limited to mature T cells, as CD28 has also been shown to augmeii: CD3-and CD2-induced thymocyte proliferation ${ }^{9,25}$.

The signal provided by the binding of CD28 mAb cooperates with phorbol ester treatment resulting in cell proliferation that is independent of accessory cells ${ }^{26}$. However, CD28 mAb 9.3 stimulation alone did not induce T-cell proliferation $6,22,26$ or IL-2 production ${ }^{6,26,27}$. Additional studies have shown that the binding of bivalent CD28 mAb in solution to purified T cells does not affect t'ie steady-state mRNA leve's of the IL-2 receptor p55 gene 27 , a variety of lymphokines (IL-Z, IFN- $\gamma$, granulocytemacrophage colony-stimulating factor (GM-CSF), TNF- $\alpha$ ) (Ref. 28) and nuclear cncogenes (c-fos, c-myc ${ }^{29}$ and c-jun ( $T$. Lindsten, unpublished)). In addition, CD28 stimulation alone did not affect the expression of the mRNA levels of a group of nine newly identified inducible T-cell genes, all of which are inducib!e with lectin stimulation ${ }^{30}$. CD28 stimulation in conjunction with immobilized CD3 mAbs costimulates purified $T$ cells while CD28 does not costimulate cells treated with soluble CD3 mAbs ${ }^{31}$. Protein kinase $C$ membrane translocation has been shown to be much more sustained after stimulation of cells with immobilized rather than fluid phase CD3 $\mathrm{mAbs}^{32}$. Together these results suggest that the binding of soluble, bivalent CD28 mAb alone does not deliver a primary signal to cells, but exerts its potent biological effects by delivering a signal dependent upon protein kinase $C$ activation or by modifying the signal delivered by protein kinase $\tau$. In contrast, increasing the valency of anti-CD28 binding to cells can deliver a primary signal to cells ${ }^{33,34}$, perhaps as a result of activation of the phosphoinositol cycle consequent to increased receptor crosslinking (see below). It is thus likely that a number of seemingly contradictory reports with regard to direct stimulatory effects of antiCD28 are explained, at least in part, by use of anti-CD28 $\mathrm{mAb}$ preparations containing variable amounts of antibody aggregates, and by use of T-cell preparations that contain variable amounts of accessory cells.

Anti-CD28 treatment has also been found to inhibit cellular proliferation. Anti-CD28 mAb 9.3 caused dosedependent inhibition of proliferation of MHC class-IIrestricted antigen-specific T-cell clones ${ }^{4}$. Similarly, mAb 9.3 treatment inhibited autologous and allogeneic mixed lymphocyte reactions (MLR) ${ }^{6}$. Thus, the effects of CD28 stimulation differ after antigen or mitogen stimulation. The degree of crosslinking of CD28 controls, in part, stimulatory versus inhibitory activity of anti-CD28 treatment, since monovalent Fab fragments of mAb 9.3 consistently inhibit, while bivalent stimulation converts the inhibitory activity of anti-CD28 into stimulatory activity in the MLR ${ }^{35}$. These seemingly confusing results can now be interpreted more easily in view of the recent evidence for a cell surface ligand for the CD28 receptor, and ir, view of the studies showing that crosslinking of CD28 regulates coupling to the phosphoinositol cycle (see below).

While the binding of anti-CD28 mAb to $T$ cells can synergize with suboptimal doses of anti-CD3, anti-CD2 mAbs or mitogenic lectins, CD28 fails to enhance the proliferation of cells stimulated with mitogens titered to induce maximal proliferation ${ }^{28}$. These observations have led to the hypothesis that regulation of 7 -cell proliferation might not be the primary role of the CD28 receptor pathway.

Recent studies have indicated that CD28 stimulation modulates two T-cell effector functions, regulation of lymphokine secretion and cell-mediated cytotoxicity. These effects appear to be distinct from those triggered by the TCR. When T cells are stimulated to maximal proliferation by culture with anti-CD3 mAb, nearly $100 \%$ of cells enter the cell cycle ${ }^{36}$. The ac'dition of CD28 mAb to cells stimulated with optimal amounts of CD3 mAb did not result in increased proliferation, as measured by cell cycle analysis or thymidine incorporation during the first rounds of the cell cycle $\mathrm{e}^{28,37}$. Surprisingly, however, uridine incorporation in cells stimulated witn CD28 plus CD3 mAbs was augmented compared to cells stimulated with $C \cap 3$ mAb only, even under conditions where CD3-inducea proliferation was optimal28. These results showed that CD28 can enhance metabolic activity in CD3-stimulated T cells in the absence of effects on CD3-induced proliferation. Thus, the signal differs from other accessory molecules such as CD5 (Ref. 38), CD44 (Ref. 39) and MHC

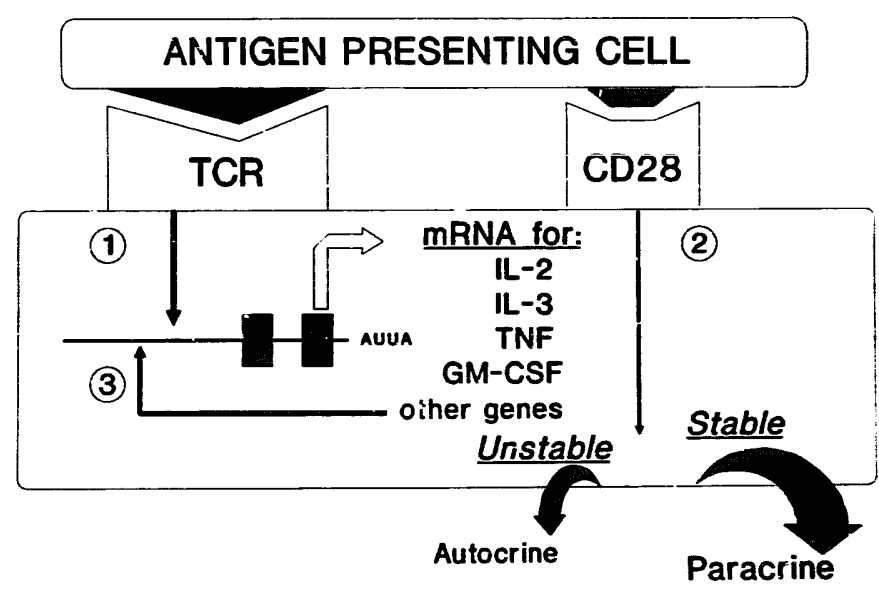

Fig. 1. Fl vnosed function of $C D 28$ receptor pathway as an autocrine-paracrine lymphokine switch. It is suggested that ine engagement of the $T$ cell by an antigen-presenting cell causes oligomerization of the $T$-cell receptor $(T C R$ ) and $C D 28$ receptor. Signal transduction by the TCR results in the initiation of lymphokine and cytokine gene transcription (step 1), and the signal provided by $C D 28$ results in stabilization of mRNA, and greatly enhanced lymiphokine production (step 2). In the absence of the signal generated hv $C D 28$, cytokine mRNA is highly unstable due to the presence of $A U$-repeat se ${ }^{-1}$ "rences in the $3^{\prime}$ untranslated region ${ }^{57,58}$, and is rapidly degraded. Late after stimulation, CD28 may also enhance transcription of IL-2 by an uncharacterized merhanism (step 3). A hypothetical mechanism is suggested whereby CD28 couses the stabilizatic , of mRNA for other non-lympiokine genes, such as an IL-2 transcription factor. In the absence of the CD28 signal (step 2), Iymphokine mRNA generated by transcriptional increases (step 1) remains limiting, and thus, is sufficient for autocrine effects. TCR activation, in conjunction with $C D 28$ receptor activation (steps 1, 2 and possibly 3), results in the secretion of large amounts of /ymphorines/cytokines that results in T-cell effector functions mediated by paracrine effects. 
Class I (Ref. 40) which appear to function by augmening signals transmitted through the TCR and, to date, have not been shown to initiate functions that are distinct from those triggered by optimal TCR stimulation.

CD28 activation specifically enhances expression of multiple cytokines

The observation that anti-CD28 treatment enhanced the metabolic activity of $\mathrm{T}$ cells suggested that CD28 might be primarily affecting a T-cell effector function independent of the cell cycle ${ }^{28}$. One of the most important of these effector functions is the prociuction of lymphokines and cytokines that provides the T-cell with a central role in numerous aspects of the immune and hematopoietic systems. Stimulation of purified T cells with mitogens or anti-CD3 mAbs has been shown to induce the expression of a wide variety of these lymphokines in an ordered temporal fashion. Furthermore, in mice, mature $\mathrm{CD4}^{+} \mathrm{T}$ cells appear frequently to express only one of two sets of lymphokine genes ${ }^{4 !}$. One set, designated $T_{H} 1$ lyinphokines, primarily mediate delayed type hypersensitivity. This set includes IL-2, IFN- $\gamma$ and lymphotoxin. In contrast, a second set of lymphokines, produced by $\mathrm{CD}^{+}$ $\mathrm{T}_{\mathrm{H}} 2$ clones, appears to be primarily involved in the regulation of antibody-mediated immune responses, and includes IL -4 and IL-5. Several lymphokines including TNF- $\alpha$, GM-CSF and IL-3 appear to be made by both types of cell line.

Aithough the human equivalent of $T_{H} 1$ and $T_{H} 2$ cells remains to be defined, when $C D 28+T$ cells are ourified from human peripheral blood, they express exclusively lymphokines derived from the $T_{H} i$ set, that is IL-2, IFN- $\gamma$. TNF- $\alpha$, lymphotoxin, GM-CSF and IL-3, when stimulated with anti-CD3 mAbs. By contrast, stimulation of peripheral $C D 28^{+} T$ cells with doses of anti-CD3 that induce optimal cellular proliferation results in the expression of only low !evels of these lymphokines ${ }^{27.28}$ that is sufficient to induce autocrine stimulation and cell cycle pros, iession of the stimulated cells but not to cause an accumulation of significant levels of $1 \mathrm{~L}-2$ in the supernatant during the cellular response. When cells are co-stimulated with antiCD28 and anti-CD3, there is a 5-50-fold increase in the levels of these $T_{H} 1$ lymphokines, including IL-2, in the culture supernatant 27.28 . The addition of solubie, bivi int anti-CD28 mAb apparently leadis to a shift from autocrıne to paracrine production of these lymphokines in antiCD3-stimulated cells (Fig. 1). Thus, the CD28 receptor can be considered as a modulator of the ability of antigenactivated $T$ cells to regulate other cells as a result of the production of $T_{H} 1$ iymphokines. Since the acquisition of the ability to produce $T_{H} 2$ lymphokines during normal T-cell maturation, has not been defined in humans, the relationship between CD28 antigen expression and stimulation of IL-4 and IL-5 expression remains to be determined.

The primary mechanism by which anti-CD28 augments lymphokine production in mature $T$ cells is by inhibiting the degradation of $T_{H} 1$ lymphokine mRNAs (Fig. 1). As a result of the stabilization of mRNA ${ }^{29}$, the steady-state levels of $T_{H} 1$ lymphokine mRNA increase, leading to enhanced translation and protein secretion ${ }^{28}$. It remains to be determined whether or not CD28 can regulate the

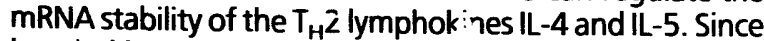
lymphokine genes are not transcribed in quiescent $T$ cells, the abs':- observations account for the fact that T cells fail to display a significant response to soluble or bivalent anti-
CD28 mAb stimulation alone: in the absence of transcription, a mechanism to stabilize mRNA has no effect on steady-state mRNA levels. In addition to a primary effect on mRNA stability, co-stimulation of quiescent $T$ cells with anti-CD3 and anti-CD28 does appear to have a number of secondary effects on T-cell responses.

About six hours after stimulation of $T$ cells with antiCD28, IL-2 mRNA levels appear to be enhanced by a CD28-dependent increase in transcription as well as mRNA stability (Fig. 1, step 3; unpublished data) - an effect predicted by the observation that the increase in IL-2 production accompanying CD28 stimulation could not be accounted for simply by an effect on mRNA stability ${ }^{37}$. It is possible that this late effect on transcription may be due to enhanced stability of mRNA for lymphokine-specific transcription factors. At least one such transcription factor containing an AU-rich instability eleiment has been identified ${ }^{42}$. At a cellular level, T-ce!! proliferation continues for a substaritiallv longer per:od of time as a result of TCR and CD28 co-stimulation ${ }^{22}$, an effect presumably mediated by sustained production of lymphokines.

\section{Cyclosporine-resistant lymphokine production}

The ability to induce T-cell lymphokine expression as a result of CD28 plus phorbol ester stimulation has also helped to clarify the role of cyclosporine in inhibiting T-cell proliferation and lymphokine production. mRNA for IL-2, IFN- $\gamma$, GM-CSF and TNF- $\alpha$ can all be induced by a combination of phorbol myristate acetate (PMA) and anti-CD28 stimulation 28 . For IL-2, this presumably results from the induction of low level transcription from the AP-1 enhancer site in the IL-2 promoter, coupled with stabilization of the processed mRNA in the cytoplasm as a result of CD28 stimulation. Alternatively, this could result from the combined effects of phorbol ester and the CD28 signal acting at the level of transcription. This means of producing IL-2 is completely resistant to suppression by cyclosporine 27.43 .44 . In contrast, the major transcriptional stimulation of IL-2 mediated by an increase in intracellular calcium can be completely abolished by cyclosporine $A^{37}$. As a result, anti-CD3 stimulation, which leads to both protein kinase $C$ activation and increases in intracellular calcium1, can be separated into a cyclosporine-suppressible component dependent upon increases in intracellular calciu. $\eta$ and i non-suppressible component when CD28 cc-stirnulation is used. This result demonstrates that a factor proximal to IL-2 transcription in the calcium-dependent pathway is inhibited by cyclosporine A. Thus, it is possible that the cyclosporine-resistant T-cell proliferation commonly observed in vivo during allograft rejection is the result of an in vivo equivalent of the CD28 pathway.

\section{Effects of $C D 28$ on cytotoxicity}

Resting human T cells are noncytolytic; however, after activation and proliferation, they may differentiate into cells with cytotoxic capability. Presentation of anti-CD3 and anti-CD28 mAbs to T cells by melanoma cells via heteroconjugate anti-melsnoma/anti-CD3 and antimelanoma/anti-CD28 mAbs causes T-cell proliferation that is independent of monocytes and natural killer cells, and results in potent tumor cell killing ${ }^{45}$. This cytotoxicity is non-MHC restricted but is dependent on anti-CD3/antimelanoma and anti-CD28/anti-rnelanoma heteroconju- 
gate mAbs for targeting to tumor cells. in contrast, when purified $T$ celis are stimulated with immobilized anti-CD3 and soluble anti-CD28, the rapidly proliferating cells develop potent lytic activity to tumor cells that does not depend on heteroconjugate targeting (S. Azemove, submitted).

The mechanirm of CD28-induceci cytotoxicity remains to be determined. It is likely that the CD28 effect is due in part to increased IL-2 production. However, simple addition of IL-2 to medium does not reproduce the cytotoxic effects of CD28 stimulation, suggesting that other molecules with anti-tumor activity may be responsible ( $S$. Azemove, submitted). The potent effects of CD28 on TNF- $a$ and lymphotoxin gene expression ${ }^{28,29}$ suggests one potential mechanism. It is also possible that CD28 stimulates the expression of genes whose expression correlates with the acquisition of cytotoxic activity by $T$ cells, such as the perforin famiiy of genes ${ }^{\Delta f}$. CD28 is expressed on CD4 ${ }^{+}$ $T$ cells anc $\mathrm{CD}^{+} \mathrm{T}$ cells that have MHC-restricted cytotoxic activity"1 (see above); it is not yet known which cells are responding in the non-MHC-restricted experimental systems described above.

\section{CD26 is involved with a distinct signa! transduction pathway}

A central question conrerning the role of accessory molecules in T-cell accivation is whether or not the accessory signal is simply enhancing or sustaining the signals provided by the TCR, or whether the signal is distinct from the TCR. In the former case, biological responses might be expected to be additive to those attributabie to the T:-R, whereas in the latter case synergistic biological responses would be expected. The signal delivered by CD28 can synergize with optimal doses of calcium ionophore and phorbol ester to increase the amount of IL-2 produced by purified $T$ cells $^{37}$. These results were surprising since the signals provided by calcium ionophore and phorbol ester were previousty considered to be maximal stimuli. Furthermore, the induction of IL-2 production by CD28 plus phorbol ester stimulation is entirely resistant to the effects of cyclosporine, which profoundly inhibits IL-2. production after TCR stimulation, or after pharmacologic treatment with calcium ionophore and phorbol ester ${ }^{27,37}$. Together, these results argue strong:, that the CD28 receptor initiates or regulates a pathway distinct from the phospnatidyl inositol pathway activated by the TCR.

Rerent studies have shown that IL-3 gene expression can be induced in T cells after stimulation by plasticimmobilized CD3 $m A b^{47}$. IL-3 gene expression can be augmented by co-stimulation of cells with CD3 plus CD28 mAbs. However, unlike other lymphokine genes such as IL-2, TNF- $\alpha$ and GM-CSF, IL-3 gene expression could not be induced by the combination of protein kinase $C$ stimulation (provided by phorbol esters) and CD28 stimulation. Previous studies have shown that soluble, bivalent antiCD28 mAb plus phorbol ester stimulation does not increase intracellular calcium concentration $44: 48$. IL-3 gene expression appears to have an obligate requirement for increased intracellular calcium concentration, since phorbol ester plus calcium ionophore stimulation did result in IL-3 gene expression ${ }^{47}$.

There is controversy concerning the biochemical nature of the signals provided by the CD28 pathway. The potent effects of CD28 on lymphokine secretion occur in the absence of anti-CD28 eifects on intracellular $\left[\mathrm{Ca}^{2+}\right]$ (Ref. 48) or protein kinase $C$ activation ${ }^{31}$. The fact that the
CD28 signal occurs in the presence of optimal calcium and protein kinase C stimulation further argues that the CD28 pathway involves signal transduction distinct from activation of phospholipase $C^{37}$. Bivalent anti-CD28 mAb 9.3 stimulation with $F(a b)^{\prime} 2$ antibody preparations is as effective at eliciting lymphokine production as intact antibody preparations, indicating that the signal is independerit of Fc receptors ${ }^{6.22}$, while Fab fragments of mAb 9.3 retain binding yet do not cause lymphokine production.

Increases in intracellular $\left[\mathrm{Ca}^{2+}\right]$ and inositol phosphate production can occur after CD28 9.3 mAb stimislation ${ }^{31.34,49}$, however, these effects have been shown to require additional crosslinking, such as that provided by the use of a second step anti-immunoglobulin reagent ${ }^{\mathrm{ag}}$. Multivalent crosslinkina of CD28 on the T-cell surface can lead to the expression of the $\mathbb{L}-2$ receptor $p 55$ gene, leading to IL-2 responsiveness in the absence of antigenic stimulation 34,50 . However, the inositol phosphate produ:tion and calcium mobilization induced by crosslinking the CD28 receptor differs from that induced by the TCR in that pretreatment of cells with phorbol esters enhances the CD28 signal while the TCR signal is inhibited ${ }^{34}$. Since these differences in signalling can not be attributed to phorbol-ester-induced decreases in receptor expression, the coupling of phospholipase C to CD28 and to the TCR probably differs. Cholera toxin and agents that increase intracellular CAMP inhibit anti-CD3 plus phorbol-esterstimulated T-cell proliferation while anti-CD28 plus phorbol-ester-stimulated T-cell proliferation is resistant to these agents ${ }^{43.48}$, which provides further evidence that CD3 and CD28 use distinct signal transduction pathways. Furthermore, PHA-induced proliferation of T cells is suppressed by calcitrin (1.25-dihydroxyvitamin $D_{3}$ ), while PHA plus CD28 stimulated proliferation is resistant to calcitriol $^{51}$. Thius, it is likely that CD2\& regulates two signal transduction pathways, one mediated by phospholipase $C$ activation that requires a high degree of receptor crosslinking, and a second, presi:mably mediated by an uncharacterized second messe. 1 ger, that is independent of the TCR, requires minimal CD28 receptor oligomerization and results in mRNA stability ${ }^{34}$.

CD28 stimulation with bivalent, soluble mAb causes smail increases in cellular cGMP concentration in the Jurkat T-cell line ${ }^{48}$. However, these effects are not sufficient to account for the effects of CD28 on lymphokine production, as they do not specifically occur in primary $T$ celis, and treatment of cells with agents to increase cGivlP concentration does not enhance lymphokine mRNA levels (authors' unpublished observations). Preliminary studies indicate that CD28 does not affect tyrosine phosphorylation of the TCR $\zeta$ chain (C. June and L. Samelson, unpublished) or the tyrosine phosphorylation of other cellular substrates ${ }^{34}$, suggesting that CD28 may not affect the tyrosine kinase/phosphatase signal transduction pathway. CD3 stimulation increases serine phosphorylation of pp60c-src while CD28 stimulation does not affect the steady state level of phosphorylation of pp60c-src, further indicating that biochemisaily distinct signals are delivered by the TCR and CD28 receptors ${ }^{51}$.

\section{CD28 ligand}

The immunoglobulin-like structure of CD26 (Ref. 8), together with the potent biologic effects of CD28, predicted that it would be a receptor for a soluble growth factor or a cell-bound ligand. Recent studies by P. Linsley 
and co-workers (Oncogen Corp.) indicate that a cell surface ligand for $C D 28$ exists on antigen presenting cells ${ }^{53}$. A vector containing the CDNA for CD28 was transfected into Chinese Hamster Ovary (CHO) cells, and stable trarsfectants expressing large amounts of CD28 aritigen were obtained. Some ce!l lines specifically adhere to CD28+ CHO cells and this adherence can be prevented by antiCD28 mAb. The adhesion is also blocked by pretreatment of the cell lines with antibody to the B7/BB-1 antigen. The B7/BB-1 molecule is an activation antigen expressed on $B$ cells ${ }^{54}$; molecular cloning of the CDNA for the B7/BE-1 antigen indicates that it, like CD28, is a member of the immunoglobulin gene superfamily55. Thus, it is iikely that CD28 and B7/BB-1 form a newly recognized heterophilic cell adhesion receptor system that may be involved in B-cell antigen presentation and in T-B-lymphocyte cooperation. Furthermore, these results suggest that the potent effects of CD28 mAbs observed in vitro may be mediated in vivo by oligomerization of the $\mathrm{CD} 28$ receptor by a cell surface ligand (Fig. 1). Finally, it is possible that the CD28 ligand can deliver the co-stimulatory signal described by Schwartz and colleagues that results in either T-cell activation or anergy ${ }^{56}$.

\section{Future directions}

Many questions regarding the $C D 28$ antigen remain to be answered. The studies reviewed here demonstrate the unique nature of the biochemical signal provided by the CD28 receptor pathway, and suggest that o role for the CD28 antigen is to augment and sustain immune responses by regulating cytokine production. Characterization of the CD28 signal at the molecular level will certainly lead to a more complete knowledge of the regulation of cytokine production by $T$ cells. It is clear that further progress in understanding the role of CD28 in the intact immune system is dependent on future studies of thie $\bar{C} \bar{D} \mathbf{2} \mathbf{8}$ receptor in celi adhesion as weli as the second messengers involved in CD28-induced signal transduction.

We thank our colleagues Jim Allison, Larry Samelson, Tullia Lindsten, Jeffrey Leiden, Larry Turka, Kelly Jackson, Mary Fletcher and Susan Azemove for sharing unpublished data Nancy Craighead and Greg Stella for excellent technical assistance and Stephen Shaw for review of the manuscript.

\footnotetext{
Rieferences

1 Weiss, A. and Imboden, J.B (1987) Adv. Immunol. 41, 1-38

2 Weaver, C.T and Unanue, E.R. (1990) Immunol. Today 11, 49-55

3 Damle. N.K., Hansen, J.A., Good, R.A. and Gupta, 5. (1981) Proc. Natl

Acad. Sci. USA 78, 5096-5098

4 Lesstauer, W., Koning. F.. Ottenhoff, T. et al. (1986) Eur. J. Immunol. 16. $1289-1296$

5 Hanseri, J.A., Martin, P.J. and Nowinski, R.C. (1980) /mmunogenetics 10 247-260

6 Martin, P.j., Ledbetter, J.A., Morishita, Y. et al. (1986)

J. Immunol. 136, 3282-3287

7 Lesslauer, W. and Gmünder, H. (1986) Mol. Immunol. 23, 271-278

8 Aruffo. A. and Seed, B. (1987) Proc. Natl Acac. Sci. USA 84, 8573-8577

9 Turka, L.A., Ledbetter, J.A., Lee, K., June, C.H. and Thompson, C.B. (1990) J. Immunol. 144, 1646-1653

10 Pierres, A. Cerdan, C., Lopez, M., Nawas, C. and Olive, D. (1990) J. Immund. 144, 1202-1207

11 Darnle, N.K.. Mohagheghpour, N., Hansen, J.A. and Engleman, E.G. (1983) J. Imr.unol. 131, 2296-3300

12 Yame'a, H., Martin, P.J., Bean. M.A. et al. (1985) Eur. J. Immunol. 15,

$1164-1168$
}

13 Morishita, Y, Sao, H., Hansen, J.A. and Martin, P.J. (1989) J. Immunol. 143. 2783-2789

14 Kozbor, D., Moretta, A., Messner, H.A., Moretta, L. and Croce, C.M. (1987) J. Immunol. 138, 4128-4132

15 Poggi. A., Bottino, C., Zocchi, M.R. et al. (1987) Eur. J. Immunol. 17. $1065-1068$

16 Testi, R. and Lanier, L.L. (1939) Eur. J. Immunol. 19, 185-188

17 Rotteveel, F.T.M., Kokkelink, I., Van Lier, R.A.W. et al. (1988) J. Exp.

Med. 168, 1659-1673

18 Lum, L.G., Orcutt-Thordarson, N., Seigneuret, M.C. and Hansen, J.A.

(1982) Cell. Immunol. 72, 122-129

19 Clark, E.A. and Draves, K.E. (1987) Eur. J. Immunoi. 17, 1799-1805

20 Gross, J., St John, T. and Allison, J.P. (1990) J. Imımunol. (in press)

21 Gmünder, H. and Lesslaupr, W. (1984) Eur. J. Biochem. 142, 153-160

22 Ledbetter, J.A., Martin, P.J., Spooner, C.E. et al. (1985) J. Immunol.

135, 2331-2336

23 Ledbetter, J.A. Rabinovitch, P.S., Hellstrom, I. et al. (1988) Eur. J.

Immunol. 18, 1601-1608

24 Van Lier, R.A., Brouwer, M. and Aarden, L.A. (1988) Eur. J. Immunol.

18, 167-172

25 Yang, S.Y., Denning, S.M., Mizuno, S., Dupont, B. and Haynes, B.F.

(1988) J. Exp. Med. 168, 1457-1468

26 Hara, T., Fu, S.M. and Hansen, J.A. (1985) J. Exp. Med. 161.

$1513-1524$

27 June, C.H., Ledbetter, J.A., Gillespie, M.M., Lindsten, T. and Thompson, C.B. (1987) Mol. Cell. Biol. 7. 4472-4481

28 Thompson, C.B., Lindsten, T., Ledbetter, J.A. et al. (1989) Proc. Natl Acad. Sci. USA 86, 1333-1337

29 Lindsten, T., June, C.H., Ledbetter, J.A., Stella, G. and Thompson, C.B.

(1989) Science 224, 339-343

30 Irving, S.G., June, C.H., Zipfel, P.F., Siebenlist, U. and Kelly, K. (1989)

Mol. Cesi. Biol. 9, 1034-1040

31 Weiss, A., Manger, B. and Imboden, J. (1986) J. Immunol. 137.

819-825

32 Manger, B., Weiss, A., Imboden, J. et al. (1987) J. Immunol.

$139,2755-2760$

33 Moretta, A., Pantaleo, G., Lopez-Botet, M. and Moretta, L. (1985)

J. Exp. Med. 162, 823-838

34 Ledbetter, I.A., Imboden, J.B. and Schieven, G.L. et al. (1990) Blood (in press)

35 Damle, N.K., Doyle, L.V., Grosmaire, L.S. and Leduetter, J.A. (1988)

J. Immunol. 140, 1753-1761

36 Weber, W.E !., Buurman, W.A., i zndermeeren, M.M.P.P. and Raus,

J.C.M. (1985) j. Immunol. 135, 2337- 2342

37 June. C.H., Ledbetter, J.A., Lif.dste:ı, T. and Thompson, C.B. (1989)

J. Immunol. 143, 153-161

38 June, C.H. Rabinovitch, P.S. and Ledbetter, J.A. (1987) J. Immunol. 138, 2782-2792

39 Huet, S., Groux, H., Caillou, B. et al. (1989) J. Immunol. 143, 798-801

40 Geppert. T.D., Wacholtz, M.C., Patel, S.S., Lightfoot, E. and Lipsky, P.E.

(1989) J. Irnmunol. 142, 3763-3772

41 Mosmann, T.R. and Coffman, R.L. (1989) Annu. niev. Immunol. 7.

145-173

42 Miyamoto, M., Fujita, T., Kimura, Y. et al. (1988) Cell 54, 903-913

43 Bjorndahl, J.M., Sung, S.S., Hansen, J.A. and Fu, S.M. (1989) Eur. J.

Immunol. 19, 881-887

44 Bloemena, E., Van Oers, R.H., Weinreich, S., Stilma-Meinesz, A.P. et al.

(1989) Eur. J. Immunol. 19, 943-946

45 Jung, G., Ledbetter, J.A. and Muller-Eberhard, H.J. (1987) Proc. Nat/

Acad. Sci. USA 84, 4611-4615

46 Lichtenheld, M.G., Olsen, K.J., Lu. P. et al. (1988) Nature 335, 448-451

47 Guba, S.C., Stella, G., Turka, L.A. et al. (1989) J. Clin. Invest. 84.

$1701-1706$

48 Ledbetter, J.A., Parsons, M., Martin, P.J. et al. (1986) J. Immunol. 137, 3299-3305

49 Ledbetter, J.A., June, C.H., Grosmaire, L.S. and Rabinovitch, P.S. (1987) Proc. Natl Acad. Sci USA 84, 1384-1388

50 Baroja, M.L., Ceuppens, J.L., van Damme, J. and Billiau, A. (1988)

J. Immunol. 141, 1502-1507

51 Vanham, G., Ceuppens, J.L. and Boullon, R. (1989) Cell. Immunol. 124, 320-333

52 Ledbetter, J.A., Gentry, L.E., June, C.H., Rabinovitch, P.S. and Purchio, A.F. (1987) Mol. Cell. Biol 7, 650-656

53 Linsley, P. Clark, E.A. and Ledbetter, J.A. (1990) Proc. Natl Acad. Sci. USA (in press)

54 Yokochi, T., Holly, K.D. and Clark, E.A. (1982) J. Immunol. 128

823-827

55 Freemañ, G.J., Freedman, A.S., Segil, J.M. et al. (1989) J. Immunol. 143 , $2714-27 \div 2$

56 Mueller, D.L., Jenkins, M.K. and Schwartz, R.H. (1989) Annu. Rev. Immunol. 7, 445-480

57 Caput, D., Beutler, B., Hartog, K. et al. (1386) Proc. Natl Acad. Sci. USA

83, 1670-1674

58 Shaw, G. and Kamen, R. (1986) Cell 46, 659-667 